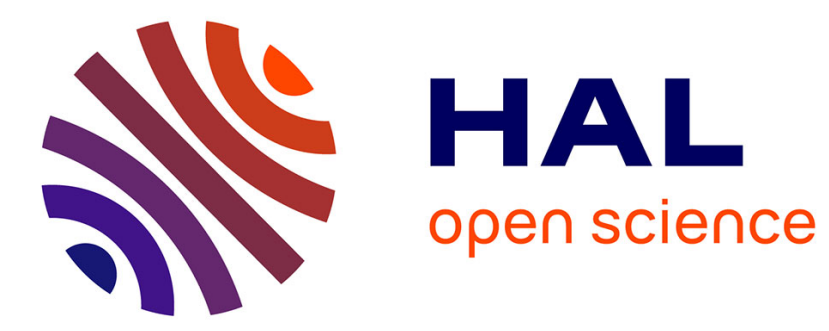

\title{
Methionine one-electron oxidation: Coherent contributions from radiolysis, IRMPD spectroscopy, DFT calculations and electrochemistry
}

Debora Scuderi, Jacqueline Bergès, Pedro de Oliveira, Chantal Houée-Levin

\section{- To cite this version:}

Debora Scuderi, Jacqueline Bergès, Pedro de Oliveira, Chantal Houée-Levin. Methionine one-electron oxidation: Coherent contributions from radiolysis, IRMPD spectroscopy, DFT calculations and electrochemistry. Radiation Physics and Chemistry, 2016, 10.1016/j.radphyschem.2016.05.007 . hal01320731

\section{HAL Id: hal-01320731 \\ https://hal.sorbonne-universite.fr/hal-01320731}

Submitted on 24 May 2016

HAL is a multi-disciplinary open access archive for the deposit and dissemination of scientific research documents, whether they are published or not. The documents may come from teaching and research institutions in France or abroad, or from public or private research centers.
L'archive ouverte pluridisciplinaire HAL, est destinée au dépôt et à la diffusion de documents scientifiques de niveau recherche, publiés ou non, émanant des établissements d'enseignement et de recherche français ou étrangers, des laboratoires publics ou privés. 


\section{ACCEPTED MANUSCRIPT}

Methionine one-electron oxidation: coherent

contributions from radiolysis, IRMPD spectroscopy, DFT calculations and electrochemistry

Debora Scuderi $^{1,2}$, Jacqueline Bergès ${ }^{3,4}$, Pedro de Oliveira ${ }^{1,2}$, Chantal Houée-Levin ${ }^{1,2^{*}}$

${ }^{1}$ Laboratoire de Chimie Physique, UMR 8000, Université Paris-Sud, 91405 Orsay Cedex, France.

${ }^{2}$ CNRS, UMR 8000, Bldg 350, 91405 Orsay Cedex, France.

${ }^{3}$ Laboratoire de Chimie Théorique, UMR 7616, Université Pierre et Marie Curie, 4 Place Jussieu, 75252 Paris Cedex 5, France

${ }^{4}$ CNRS, UMR 7616, 75252 Paris Cedex 5, France

Corresponding author:

Prof. Chantal Houée Levin

Chantal.houee@u-psud.fr

Laboratoire de Chimie Physique, CNRS, UMR 8000, Université Paris-Sud, F-91405

Orsay, France

\section{Abstract}

Methionine is an essential amino acid, unfortunately prone to oxidation. The mechanism of its oxidation by ${ }^{\circ} \mathrm{OH}$ radicals has been studied for more than 40 years and still remains misunderstood. We have reinvestigated the oxidation of this residue in model peptides, aiming at i) improving the identification of free radicals by the use of more modern quantum chemistry methods; ii) reinvestigating the one-electron reduction potentials as a function of the position in the sequence; iii) identifying the final compounds, which were still unknown; iv) reinvestigating the intramolecular electron transfer (IET) involving this residue.

\section{Keywords:}

Methionine oxidation, sulfoxide, pulse radiolysis, mass spectrometry, IRMPD, DFT computations, electrochemistry. 


\section{Introduction}

It is well known that protein residues are all susceptible to be oxidized by the so-called "Reactive Oxygen Species" (ROS), i.e. hydrogen peroxide, oxygen free radicals and various oxygen-containing free species such as the NOx, hypochlorite etc [1]. Protein oxidation is a major event in all diseases and in ageing. Among the various residues, methionine (Met) plays a central role. It is easily oxidized by all ROS. The single product that was known is methionine sulfoxide (MetSO), which can even be oxidized to the sulfone. More importantly, methionine sulfoxide can be enzymatically reduced by the methionine sulfoxide reductases, hence the couple MetSO/Met is considered as a protection against ROS.

Despite this wealth of knowledge, many points remain to be elucidated. Oxidation by ${ }^{\circ} \mathrm{OH}$ radicals leads to methionine free radicals having an interesting 2-centre, 3-electron (2c-3e) bond because the methionine sulphur-centred radical cation is stabilized by donation of any free doublet from a vicinal atom. In peptides and proteins, it can be nitrogen, oxygen or another sulphur atom [2,3]. The identification of these free radicals was performed by their absorption spectra obtained in pulse radiolysis or in flash photolysis $([4,5]$ and references therein), by EPR and CIDNP [6-8]. The reduction potential of methionine has never been measured and one relies on that of small compounds like dimethyl sulphide, without knowing in what sense the neighbouring residues could modify it. As for the final compounds, very few investigations have been reported. In proteins only methionine sulfoxide has been detected. In small peptides, decarboxylation can occur when Met is the C-terminus [9]. However, several other processes could take place. Finally we have reinvestigated the problem of intramolecular electron transfer (IET) involving methionine in peptides.

We have addressed these four points by performing again calculations by quantum chemistry based upon recent knowledge about the adequacy and the precision of some methods and investigated the topology of these free radicals. We have made new attempts to measure the redox potentials of the Met+/Met couple in some model peptides and shown that it does depend on the position in the polypeptidic chain. Finally, thanks to mass spectrometry coupled to Infrared Multiple Photon Spectroscopy in the gas phase (IRMPD) we have shown that compounds other than the sulfoxide are formed. In what follows, we summarize some of our most prominent results and we take the example of the peptides Met Val and Val Met to enlighten some of the problems encountered. 


\section{ACCEPTED MANUSCRIPT}

\section{Materials and methods}

\section{PRODUCTS}

Methionine, methionine sulfoxide and Catalase (Cat) (bovine liver, suspension in water) were obtained from Sigma (France) and used without purification. The peptides were purchased at Sigma Aldrich (L'isle d'Abeau, France) or at Bachem (Switzerland). They were used as received. The catalytic activity of Cat was checked using a solution $1 \mathrm{mM}$ of $\mathrm{H}_{2} \mathrm{O}_{2} .1 \mu \mathrm{L}$ of the suspension was added to the solutions before irradiation. Water was obtained either from an Elga Maxima or from a Millipore system (conductivity $10^{-18}$ Siemens).

\section{GAMMA RADIOLYSIS}

$\gamma$-irradiations were carried out using the panoramic ${ }^{60} \mathrm{Co} \gamma$-source IL60PL Cis-Bio International (France) in the University Paris-Sud (Orsay, France). The dose rate was determined by Fricke dosimetry [10] and kept constant at around $30 \mathrm{~Gy} \mathrm{~min}^{-1}$. Samples were gently purged while stirring under a nitrous oxide $\left(\mathrm{N}_{2} \mathrm{O}\right)$ atmosphere for approximately 60 min before irradiation. $\mathrm{N}_{2} \mathrm{O}$ was delivered by ALPHA GAZ. Its global purity is $99.998 \%$.

All irradiations were performed at room temperature.

The well-known method of scavengers [10] allows a quantitative production of free radicals according to the following reactions. The chosen oxidant species was the ${ }^{\circ} \mathrm{OH}$ radical produced by $\gamma$ radiolysis of $\mathrm{N}_{2} \mathrm{O}$-saturated aqueous solutions:

$$
\begin{aligned}
& \mathrm{H}_{2} \mathrm{O} \rightarrow{ }^{\circ} \mathrm{OH}, \mathrm{H}^{\bullet}, \mathrm{e}^{-} \text {aq } \\
& \mathrm{H}_{2}, \mathrm{H}_{2} \mathrm{O}_{2}, \mathrm{H}^{+}, \mathrm{OH}^{-} \\
& \mathrm{eq}^{-}+\mathrm{N}_{2} \mathrm{O}+\mathrm{H}_{2} \mathrm{O} \rightarrow{ }^{\circ} \mathrm{OH}+\mathrm{OH}^{-}+\mathrm{N}_{2}
\end{aligned}
$$

The radiation chemical yield (G) is equal to $0.55 \mu \mathrm{mol} \mathrm{J}^{-1}$ (equations 1 and 2). $\mathrm{H}$ atoms are

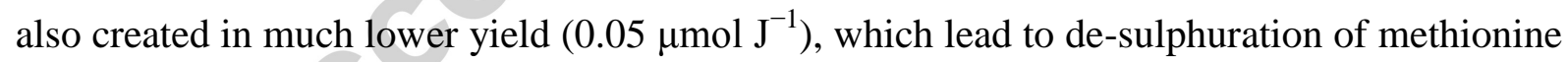
[11]. The $\mathrm{H}_{2} \mathrm{O}_{2}$ yield is also lower $\left(0.07 \mu \mathrm{mol} \mathrm{J}{ }^{-1}\right)$. Catalase was added to remove it in order to prevent the two-electron oxidation of methionine [12].

\section{ELECTROCHEMISTRY}

Cyclic voltammetry was carried out with a three-electrode system connected to a EG\&G PAR 273A potentiostat which was computer-controlled via the M270 software. The system consisted of a Teflon electrochemical cell containing a boron-doped diamond working electrode, a platinum gauze counter electrode and a saturated Calomel reference electrode (SCE). A sodium perchlorate (VWR, France) $0.1 \mathrm{M}, \mathrm{pH}=2.0$ buffer was prepared with pure 


\section{ACCEPTED MANUSCRIPT}

water obtained from a Milli-RiOs 8 unit followed by a Milli-Q academic purification set (water resistivity: $18.2 \mathrm{M} \Omega . \mathrm{cm}$ ). Solutions were made with the dipeptides Gly-Met, Met-Gly, Met-Met, Val-Met and Met-Val, Met enkephalin, from Bachem (Switzerland), and with the amino acid methionine (Met) from Sigma (France), used as received from the suppliers. Electrolysis was performed in $20 \mathrm{mM}$ phosphate buffer, $\mathrm{pH}=7.0$, in a three electrode cell with a glassy carbon stick as the working electrode, whose potential was set at $+1.5 \mathrm{~V}$ vs. SCE for 3 hours. For comparison, solutions having the same concentration were subject to the same procedures except for the applied potential difference. Blanks consisting of pure buffer were treated likewise. All solutions had a concentration of $1 \mathrm{mM}$ in their solutes and were thoroughly de-oxygenated with argon prior to the electrochemistry experiments.

\section{MS OPERATIONS}

IR multiple photon dissociation (IRMPD) is a multi-step resonant absorption process relying on intramolecular vibrational energy redistribution (IVR) [13]. Infrared spectra are obtained by monitoring the abundance of parent and fragment ions. If $\mathrm{F}$ is the sum of the abundances of the fragment ions produced by IRMPD and $\mathrm{P}$ the one of the parent ion, our IRMPD spectra correspond to the plot of $-\ln [\mathrm{P} /(\mathrm{F}+\mathrm{P})]$ as a function of the IR wavenumber.

The IRMPD spectra in the $800-2000 \mathrm{~cm}^{-1}$ energy range have been obtained with the IR beam of the CLIO FEL coupled to the modified Paul ion trap or a FT-ICR mass spectrometer. Details on the performance of our modified Bruker Esquire 3000+ were already published [14]. Different electron energies were used (40-44 MeV). Typical average powers were about $1 \mathrm{~W}$ around $1000 \mathrm{~cm}^{-1}$ and $0.4 \mathrm{~W}$ near $2000 \mathrm{~cm}^{-1}$.

\section{COMPUTATIONAL METHODS}

DFT methods and basis sets. To the best of our knowledge no DFT method has been specifically adapted to the calculations of redox potentials. In this work, we have chosen two DFT hybrid methods (BH\&HLYP and PBE0) because of their different properties concerning free radicals.

We used the relatively small basis set 6-31G(d) (SB) and the greater basis set 6$311+\mathrm{G}(2 \mathrm{~d}, 2 \mathrm{p})(\mathrm{GB})$ considering the experimental and the theoretical difficulties linked to measurements of redox potentials.

QM/MM calculations. The computations were performed thanks to the Gaussian G09 package [15] using the QM/MM method (Oniom). In this procedure, the polypeptide was 


\section{ACCEPTED MANUSCRIPT}

divided into two layers which were treated with different levels of calculations. The Quantum Mechanics (QM) method chosen was the DFT method pbe0/6-31G(d). For the Molecular Mechanics (MM) method, we used the empirical potentials uff with the electrostatic charges embedded (Qeq).

Solvation. Solvation effects were accounted for with the COSMO option for the Polarised Continuum Model CPCM considering an aqueous environment. Some calculations were also performed with IEFPCM that gave identical results.

Redox potentials. The one-electron reduction potentials were calculated as described in [16]. For each dipeptide, the Gibbs energies $\Delta \mathrm{G}_{1}$ and $\Delta \mathrm{G}_{2}$ (in $\mathrm{kJ} \mathrm{mol}^{-1}$ ) for the molecule and the cation species, respectively, relative to the molecule of lowest energy (taken as reference, $0 \mathrm{~kJ} \mathrm{~mol}{ }^{-1}$ ) were calculated. $\Delta \mathrm{G}_{(\mathrm{aq}) \mathrm{S}}$ is thus equal to $\Delta \mathrm{G}_{1}-\Delta \mathrm{G}_{2}$. Calculations were performed with the Gaussian09 package [15].

\section{Results and discussion}

CAN WE MEASURE THE REDOX POTENTIAL OF METHIONINE RESIDUES BY CYCLIC VOLTAMMETRY?

All the compounds studied gave rise to irreversible responses in cyclic voltammetry carried out with a boron-doped diamond electrode. Determining the redox potential of an irreversible couple exhibiting just the oxidation wave is not trivial, even if it may be estimated under certain circumstances ([42] and references therein). We compare wave onset potential values ( $\mathrm{E}_{\text {onset, }}$ the values at which the current starts increasing) and anodic peak potential values $\left(\mathrm{E}_{\mathrm{pa}}\right)$ and mention some trends that stand out.

Oxidation of Met and Met-Met. The $\mathrm{E}_{\text {onset }}$ values coincide for both Met and Met-Met $\left(\mathrm{E}_{\text {onset }}=\right.$ 1.27 V, Figure 1 and Table 1) [17]. The current magnitude for the Met-Met wave was roughly two-fold that of Met, as one would expect for a molecule having two $-\mathrm{SCH}_{3}$ groups. The oxidation wave for Met-Met peaks $0.13 \mathrm{~V}$ beyond that of $\operatorname{Met}\left(\mathrm{E}_{\mathrm{pa}}=1.65 \mathrm{~V}\right.$ vs. $\left.\mathrm{E}_{\mathrm{pa}}=1.52 \mathrm{~V}\right)$, an indication that the former may be slightly more difficult to oxidize than the latter.

Oxidation of Gly-Met and Met-Gly. Gly-Met, like the previous two compounds, starts being oxidized at $\mathrm{E}_{\text {onset }}=1.27 \mathrm{~V}$, and its less intense wave when compared to that of Met may be explained by a smaller diffusion coefficient (Figure 1). Met-Gly is more difficult to oxidize 


\section{ACCEPTED MANUSCRIPT}

that Gly-Met, which is confirmed by both the wave onset potentials $\left(\mathrm{E}_{\text {onset }}=1.37 \mathrm{~V}\right.$ vs. $\mathrm{E}_{\text {onset }}$ $=1.27 \mathrm{~V})$ and the anodic peak potentials $\left(\mathrm{E}_{\mathrm{pa}}=1.75 \mathrm{~V}\right.$ vs. $\mathrm{E}_{\mathrm{pa}}=1.57 \mathrm{~V}$, Table 1$)$. If the redox potential follows the same trend as the $\mathrm{E}_{\mathrm{pa}}$ values, we may expect the redox potential of MetGly to be ca. $0.2 \mathrm{~V}$ higher than that of Gly-Met. Surprisingly, the anodic peak current, $\mathrm{I}_{\mathrm{pa}}$, is higher $(\approx 50 \%)$ for Met-Gly than for Gly-Met, a result which is not easy to rationalize.

Oxidation of Met-Val and Val-Met. Like Gly-Met and Met-Gly, the behaviors of the dipeptides Val-Met and Met-Val are quite distinct. On the one hand, Val-Met has a $\mathrm{E}_{\text {onset }}$ very close to that of Met on its own, but the anodic peak is reached earlier, at $\mathrm{E}_{\mathrm{pa}}=1.48 \mathrm{~V}$, meaning that the methionine residue in this dipeptide is easier to oxidize (Figure 1 and Table 1). Interestingly, its oxidation peak current $i_{p a}$ is about $10 \%$ lower than that of Met (55.5 vs. $62.0 \mu \mathrm{A})$, which may be explained by a smaller diffusion coefficient for Val-Met when compared to Met, due to the larger size of the former. On the other hand, Met-Val starts being oxidized at a clearly higher wave onset potential, $\mathrm{E}_{\text {onset }}=1.32 \mathrm{~V}$, a process that is $0.05 \mathrm{~V}$ less favorable than for Val-Met. This trend had previously been observed for Gly-Met and MetGly [17] and suggests that when Met is present in dipeptides, the Met residue is more difficult to oxidize when it occupies the N-terminal position. Having said that, the shift in $\mathrm{E}_{\mathrm{pa}}$ is less pronounced in the case of Met-Val and Val-Met $\left(\mathrm{E}_{\mathrm{pa}}=1.55 \mathrm{~V}\right.$ vs. $\left.\mathrm{E}_{\mathrm{pa}}=1.48 \mathrm{~V}\right)$ than in the case of Met-Gly and Gly-Met $\left(\mathrm{E}_{\mathrm{pa}}=1.75 \mathrm{~V}\right.$ vs. $\left.\mathrm{E}_{\mathrm{pa}}=1.57 \mathrm{~V}\right)$, but the fact that some peaks are poorly defined leaves some room for uncertainty regarding their accurate positions. 


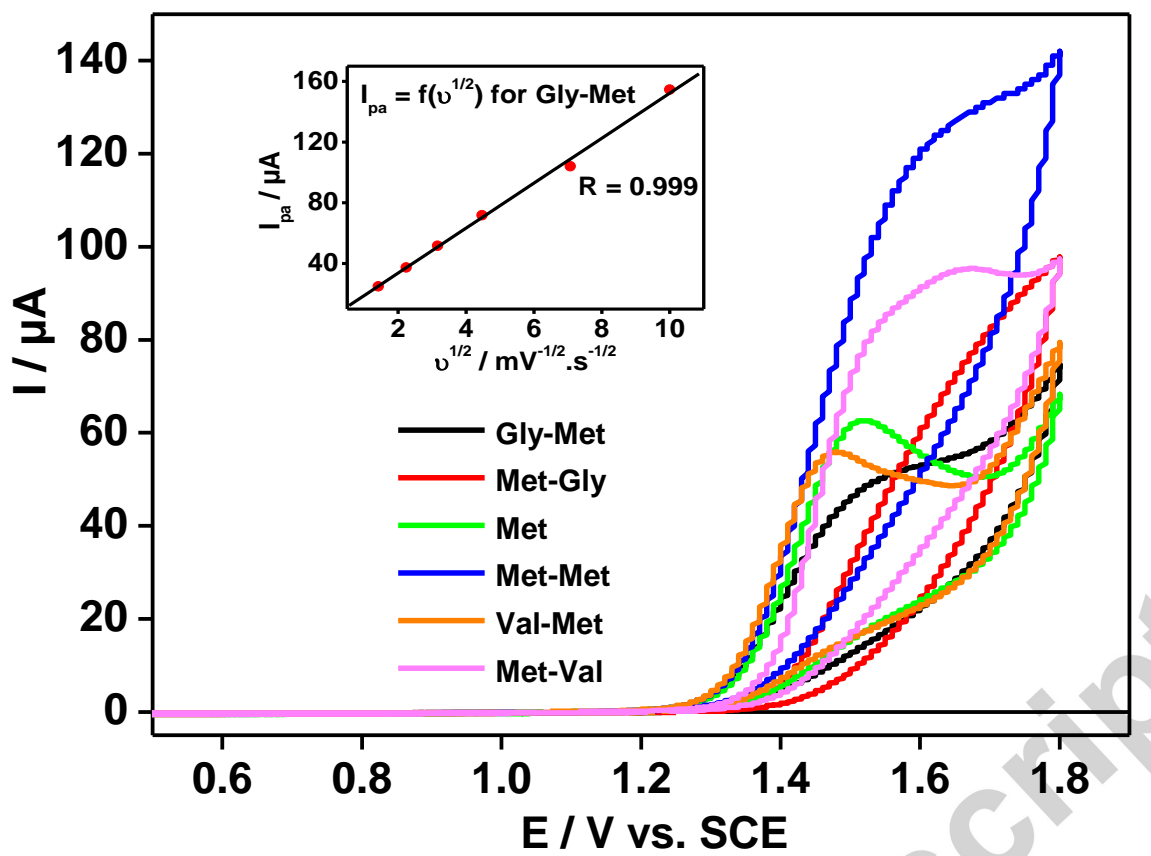

Figure 1: Cyclic voltammograms of $1 \mathrm{mM}$ solutions of Gly-Met, Met-Gly, Met, Met-Met, Val-Met and Met-Val, in sodium perchlorate $0.1 \mathrm{M}, \mathrm{pH}=2.0 \mathrm{buffer}$, at $10 \mathrm{mV} / \mathrm{s}$. Inset: dependence of the anodic peak current, $\mathrm{i}_{\mathrm{pa}}$, on the square root of the scan rate, $v^{1 / 2}$, for a $1 \mathrm{mM}$ solution of Gly-Met.

\begin{tabular}{|c|c|c|}
\hline Compound & $\mathrm{E}_{\text {onset }}(\mathrm{V}$ vs. SCE) & $\mathrm{E}_{\mathrm{pa}}(\mathrm{V}$ vs. SCE) \\
\hline Met & $1.27(1.51)$ & $1.52(1.76)$ \\
\hline Met-Met & $1.27(1.51)$ & $1.65(1.89)$ \\
\hline Gly-Met & $1.27(1.51)$ & $1.57(1.81)$ \\
\hline Met-Gly & $1.37(1.61)$ & $1.75(1.99)$ \\
\hline Val-Met & $1.27(1.51)$ & $1.48(1.72)$ \\
\hline Met-Val & $1.32(1.56)$ & $1.55(1.79)$ \\
\hline
\end{tabular}

Table 1. Oxidation wave onset potentials, $\mathrm{E}_{\mathrm{onset}}$, and peak potentials, $\mathrm{E}_{\mathrm{pa}}$, (V vs. SCE) for Met, MetMet, Gly-Met, Met-Gly, Val-Met and Met-Val. The values in parenthesis are in V vs. NHE. 


\section{ACCEPTED MANUSCRIPT}

Surprisingly, the peak current for Met-Val is more than $30 \%$ higher compared to that of Met and there seems to be a second oxidation peak at $\mathrm{E}_{\mathrm{pa}}=1.67 \mathrm{~V}$. These results are hard to rationalize, but possible explanations are the following: i) Met-Val adopts a conformation that renders its diffusion coefficient higher than that of Met, which would result in a higher current; ii) either two different conformation isomers of Met-Val which co-exist in solution give rise to two separate oxidation peaks (implying that they are more than $0.1 \mathrm{~V}$ apart), or a single Met-Val conformer undergoes an oxidation process in two consecutive steps. These results are by and large verified both at lower and at higher scan rates.

The inset in figure 1 shows the dependence of the anodic peak current, $\mathrm{i}_{\mathrm{pa}}$, on the square root of the scan rate, $v^{1 / 2}$, for the dipeptide Gly-Met. The linear dependence indicates that diffusion controls the mass transport to the electrode surface. A similar behavior is exhibited by all the compounds studied.

\section{STRUCTURE OF THE METHIONINE FREE RADICALS}

We chose the set of initial conformations so that various pseudo cycles from 5 to 9membered cycles with SS, SN or SO bonds could be formed in the radical cations. We found inspiration in the protein conformations that provided us starting points (Figure 2). In order to take into account different situations of the small sequences in polypeptides or proteins, we considered both the zwitterionic forms (ZW) as models of $\mathrm{C}$ - or N-terminals and the 2methylated species as models of protein sequences.

All structures were fully optimized in their molecular and in their radical cation states, to obtain adiabatic and not vertical redox potentials. Each located stationary point was checked by evaluating harmonic frequencies. We used the geometries obtained after these optimizations with BH\&HLYP as benchmarks for the PBE0 calculations. 


\begin{tabular}{|c|c|c|}
\hline $\begin{array}{c}\text { Conformation of } \\
\text { methionine(s) } \\
\text { putative free radical }\end{array}$ & Sequence & $\begin{array}{c}\text { Ala Met from } \\
\text { human } \\
\text { thioredoxin } \\
\text { (PDB 1TOF) }\end{array}$ \\
\hline SO & $\begin{array}{c}\text { Gly Met from } \\
\text { Chymotrypsin } \\
\text { (2YT6) }\end{array}$ & $\begin{array}{c}\text { Met Met from } \\
\text { Akt (PDB 3096) }\end{array}$ \\
\hline SN & SS & \\
\hline SN &
\end{tabular}

Figure 2. Some protein sequences that may form methionine SX bonds upon oxidation. These sequences (and others of this kind) were taken as starting points for the calculations.

An examination of the DFT methods led to the conclusion that similar results were obtained both with BH\&HLYP as with the $\operatorname{CCSD}(\mathrm{T})$ approach [18-20]. We used also the PBE0 model, based on the Perdew-Burke-Erzenrhof exchange-correlation functional [21,22] and we showed that the results were totally in agreement with those of BH\&HLYP. In this paper we concentrated on results obtained in water.

The structure of the methionine free radical was thoroughly explored by DFT methods and by topological approaches [23,24]. We adopted the following nomenclature: for the SN radicals, $\mathrm{S}$ can be linked either to $\mathrm{N}$ of the amine function (SNam) or to $\mathrm{N}$ of the peptidic bond (SNpep). Also, the number of atoms in the pseudo cycle is included in the nomenclature (for instance SN5 for five atoms). Some stable structures are displayed in Figure 3.

In the SS radicals, the SS distance increased from $\mathrm{R}_{\mathrm{SS}}=2.79 \AA$ for the simplest $\mathrm{Me}_{2} \mathrm{~S} \therefore \mathrm{SMe}_{2}^{+}$up to $\mathrm{R}_{\mathrm{SS}}=2.94 \AA$ for diSETAc cation $\left(\mathrm{C}_{2} \mathrm{H}_{5}\left(\mathrm{CH}_{3}-\mathrm{CO}\right)-\mathrm{S} \therefore \mathrm{S}-(\mathrm{CO}-\right.$ $\left.\left.\mathrm{CH}_{3}\right) \mathrm{C}_{2} \mathrm{H}_{5}^{+}\right)$, and to $\mathrm{R}_{\mathrm{SS}}=3.01 \AA$ for the diSETA cation $\left(\mathrm{C}_{2} \mathrm{H}_{5}\left(\mathrm{CH}_{3}-\mathrm{CO}\right) \mathrm{CH}_{2}-\mathrm{S} \therefore \mathrm{SCH}_{2}-(\mathrm{CO}-\right.$ 


\section{ACCEPTED MANUSCRIPT}

$\left.\mathrm{CH}_{3}\right) \mathrm{C}_{2} \mathrm{H}_{5}$ ) [24,25]. In the Met-Met cation, the value is also relatively large (2.96 $\AA$ ). It could result not only from the geometrical constraints but also from substituent effects.

The SN radicals were studied in the peptides Met-Met, Gly-Met and Met-Gly. In water, the zwitterions SNam are not stable. In all peptides, methylated or zwitterionic, among the SN5 radical cations the energy increased with the SN bond lengths [24]. The SN distance was shorter in the SN5am radicals (around $2.45 \AA$ ) than in SN5pep1 (2.57 $\AA$ ). Intramolecular SNpep-type structures were also described by other authors following the oxidation of $\mathrm{N}$ acetylmethioninamide [26] or of c-(Met-Gly) [27].

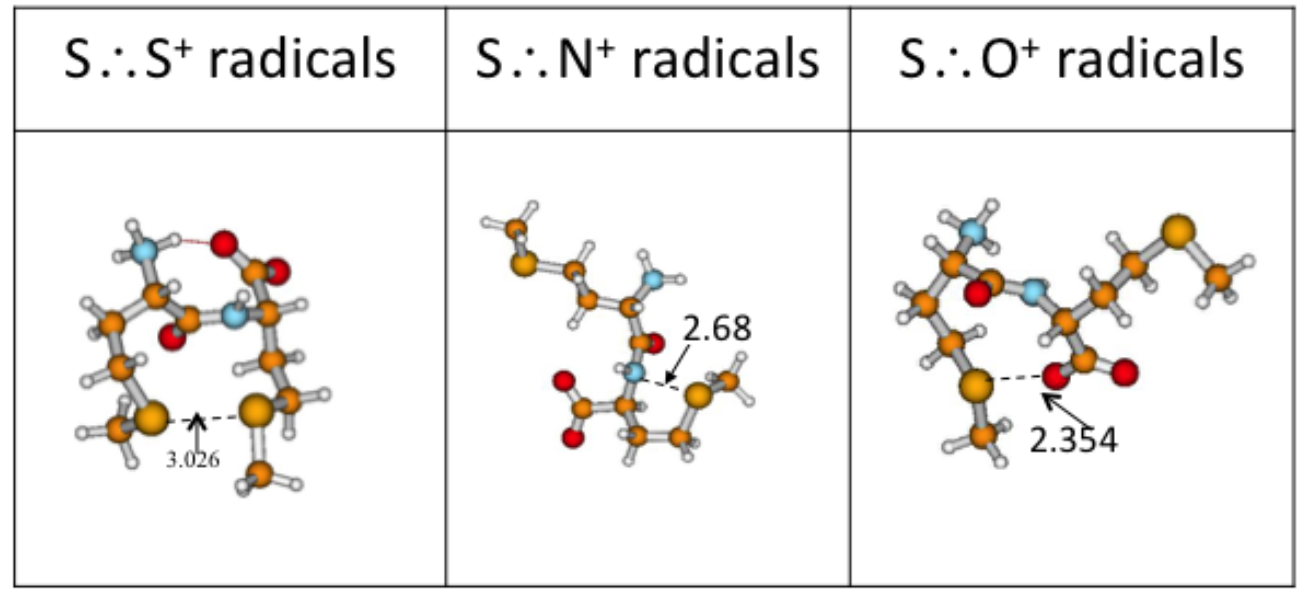

Figure 3. Some structures of stable free radicals formed from the dipeptide Met-Met in water. The distances are in $\AA$.

SO radical cations were found in Met-Gly and Gly-Met. In Met-Met they were found in water only (in vacuum the species evolved towards a $\mathrm{SN}$ radical). Cycles involving 6, 7 or 9 atoms were obtained. Upon solvation, the SO distances in SOpep radicals increased (by 0.07-0.12 A) [24]. Among the 17 structures that we have explored, the energies of the entities generally tended to increase with the SX bond length. It means that a parameter for the stability of the radical cation could be the overlap of the $\mathrm{p}$ lone pairs of the two heteroatoms involved in the 2c-3e bond. Only 7 optimized structures could be characterized. However, for Gly-Met we obtained several structures, and the most stable ones had a SO bond with the carboxylic/carboxylate group.

A topological analysis of the bond was also performed in these free radicals [24]. The main conclusions were: i) an amino nitrogen (respectively a peptidic oxygen) is more donating than a peptidic nitrogen (respectively a carboxylic oxygen), as expected from the highest 


\section{ACCEPTED MANUSCRIPT}

localization of the lone pair of the peptidic nitrogen (respectively of the carboxylic oxygen);

ii) the $2 \mathrm{c}-3 \mathrm{e}$ interaction decreases along the series as follows: $\mathrm{SN} 5 \mathrm{am} \rightarrow \mathrm{SN} 8 \mathrm{am} \rightarrow \mathrm{SN} 5$ pep1 $\rightarrow \mathrm{SN} 6$ pep; iii) the $\mathrm{S} \ldots \mathrm{O}$ bond in radical cations of dipeptides is generally best described as an electrostatic interaction. In conclusion, the nature of the $\mathrm{S} \therefore \mathrm{X}$ bond is closely related to the variation of the bond length.

\begin{tabular}{|c|c|c|c|c|}
\hline Gly & Molecule & Cation & \multicolumn{2}{|c|}{$E^{\circ}$ vs NHE (V) } \\
\hline Met & \multicolumn{2}{|c|}{ BH\&HLYP } & BH\&HLYP & PBEO \\
\hline SO7 & & & 1.61 & $-\mathrm{CO}_{2}$ \\
\hline SO7 & & & 1.59 & 1.47 \\
\hline SN5 & & & 1.19 & 1.28 \\
\hline SN5 & & & 1.06 & $-\mathrm{CO}_{2}$ \\
\hline
\end{tabular}

Figure 4: Some redox couples from the dipeptide Gly-Met and the values of the redox potentials obtained with BH\&HLYP and with PBE0 and 6/31G(d). -CO2: the free radical was not stable and underwent decarboxylation.

\section{CALCULATIONS OF REDOX COUPLE POTENTIALS}

Since the direct measurement of redox potentials by electrochemistry was not possible, we turned to calculations thereof. "Redox couples", made of a dipeptide and its radical cation, were constructed by optimizing first the structure of one of the entities of the couple (either the molecule or the radical) and then the other one starting from the previously optimized structure (Figure 4) [17]. We tried two methods (BH\&HLYP and PBE0) and two basis sets $(6-31 G(d)$ and 6-311+G(2d,2p)).

Using the smallest basis set, a striking difference between both methods is that with BH\&HLYP all radical cations were stable, whereas with PBE0 some Gly-Met and Met-Met radicals underwent decarboxylation. This is quite an interesting point since decarboxylation does occur in some peptides (vide infra). However, calculations with the largest basis set did not confirm the bond break. Using the largest basis set, the computations confirm the 


\section{ACCEPTED MANUSCRIPT}

experimentally observed tendency: the redox potentials are lower for Gly-Met (1.3-1.7 V) than for Met-Gly (1.7-2 V).

The redox potentials of the dipeptides are in the range expected for methionine amino acid. In some conformations it reached lower $(1.3 \mathrm{~V})$ or much higher values $(2 \mathrm{~V})$. Experimental results indicated such possible variations [28-30]. One might try to predict the values by looking at the atoms in the neighbourhood of the sulphur atom. Unfortunately, the nature of the atom involved in the $2 \mathrm{c}-3 \mathrm{e}$ bond does not help to rationalize the scale of redox potential. It is not so simple and one should be careful because the results might vary with the level of theory.

\section{WHAT ARE THE FINAL PRODUCTS OF METHIONINE OXIDATION BY ${ }^{\circ} \mathrm{OH}$ RADICALS?}

Large doubts remain about the final oxidized forms of the methionine residues. In studies of anaerobic one-electron oxidation of peptides or proteins, the sole final compound coming from the methionine residue is methionine sulfoxide MetSO [31-34].

Using authentic samples of methionine and its sulfoxide, we characterized the mass spectra with the fragmentation patterns coming from these two compounds and we observed the signature of the $\mathrm{S}=\mathrm{O}$ bond clearly at around $1000 \mathrm{~cm}^{-1}$. [35]. It allowed us to confirm that the sulfoxide was formed upon oxidation by ${ }^{\bullet} \mathrm{OH}$ radicals and not only by $\mathrm{H}_{2} \mathrm{O}_{2}$.

Let us now consider the results about the oxidation of Met-Val and Val-Met both by radiolysis and by electrochemistry. The CID-MS ${ }^{2}$ spectra of the dipeptides oxidized by electrolysis $\left([(\mathrm{Val}-\mathrm{MetSO}) \mathrm{H}]^{+}\right.$and $\left.[(\mathrm{MetSO}-\mathrm{Val}) \mathrm{H}]^{+}\right)$are reported in figure 5. Both mass spectra present the same fragmentation patterns observed for the samples oxidized by $\gamma$-radiolysis showing that the sulfoxide is also the main final product formed by electrolysis. The peaks with their interpretation are collected in Table 2 for both sulfoxides. The IRMPD spectra of the $\mathrm{M}+16$ peak coming from the oxidation of Met-Val by radiolysis and by electrochemistry are shown in Figure 6. The good agreement between the two experimental spectra shows that the sulfoxides have similar structures when formed in both experimental conditions. Similar results have been obtained for $\left[(\text { Val-MetSO)H }]^{+}\right.$. Some differences have been observed in the relative intensities showing that the sulfoxides formed by electrolysis are more fragile and are fragmented easier. 


\begin{tabular}{|c|c|}
\hline (Val-MetSO) $\mathrm{H}^{+}$ & 265 (parent ion) \\
& $247\left(-\mathrm{H}_{2} \mathrm{O}\right.$ from parent ion $)$ \\
& $201\left(-\mathrm{CH}_{3} \mathrm{SOH}\right.$ from parent ion $)$ \\
& $166\left(\mathrm{MetSOH}^{+}, \mathrm{y}^{\prime}{ }_{1}\right.$ fragment $)$ \\
\hline$\left.(\mathrm{MetSO}-\mathrm{Val}) \mathrm{H}^{+}\right)$ & 265 (parent ion) \\
& $247\left(-\mathrm{H}_{2} \mathrm{O}\right.$ from parent ion $)$ \\
& $219\left(\left(-\mathrm{H}_{2} \mathrm{O}-\mathrm{CO}\right.\right.$ from parent ion $)$ \\
& $201\left(-\mathrm{CH}_{3} \mathrm{SOH}\right)$ \\
& $173\left(-\mathrm{CH}_{3}-\mathrm{CH}_{2} \mathrm{SO}_{-} \mathrm{CH}_{3}\right.$ from parent ion $)$ \\
\hline
\end{tabular}

Table 2. Most intense peaks observed in the fragmentation mass spectra of the sulfoxides obtained from dipeptides oxidized by electrochemistry.

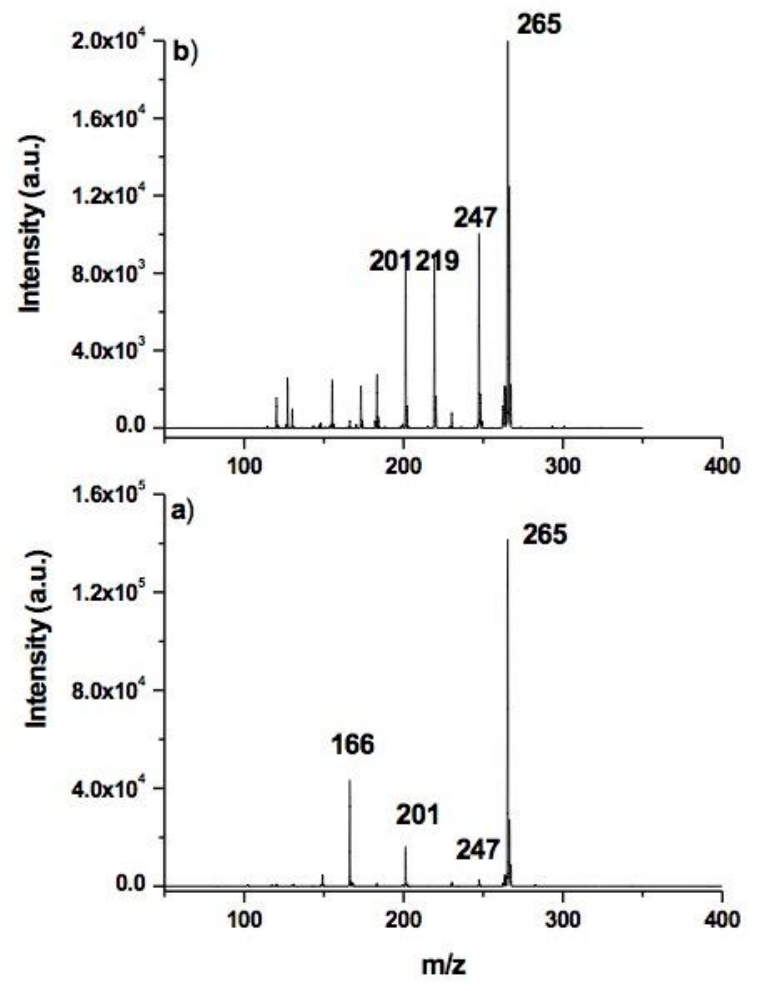

Figure 5: CID-MS ${ }^{2}$ fragmentation mass spectra of protonated electrolyzed dipeptides (a) [(ValMetSO)H] $]^{+}$and (b) (MetSO-Val)H $]^{+}$.

Similar studies were performed for various peptides, namely dipeptides containing Met (X-M and M-X, X = Val, Lys, Met and Tyr) and Met-enkephalin. They were oxidized by ${ }^{\circ} \mathrm{OH}$ 


\section{ACCEPTED MANUSCRIPT}

radicals in the absence of oxygen and in the presence of catalase to remove $\mathrm{H}_{2} \mathrm{O}_{2}$ [36]. The products detected after oxidation are gathered in Table 3.

The products corresponding to the addition of $16 \mathrm{Da}$ to each peptide were observed for all the compounds that were investigated by mass spectrometry and IRMPD spectroscopy after $\gamma$ irradiation with catalase. Thanks to the IRMPD, this mass increment was attributed to a sulfoxide, which exhibits a specific band at around $1000 \mathrm{~cm}^{-1}$, clearly observed in all the cases except for the pentapeptide Met-enkephalin. Thus, we obtained a clear proof that methionine was not oxidized in this peptide.

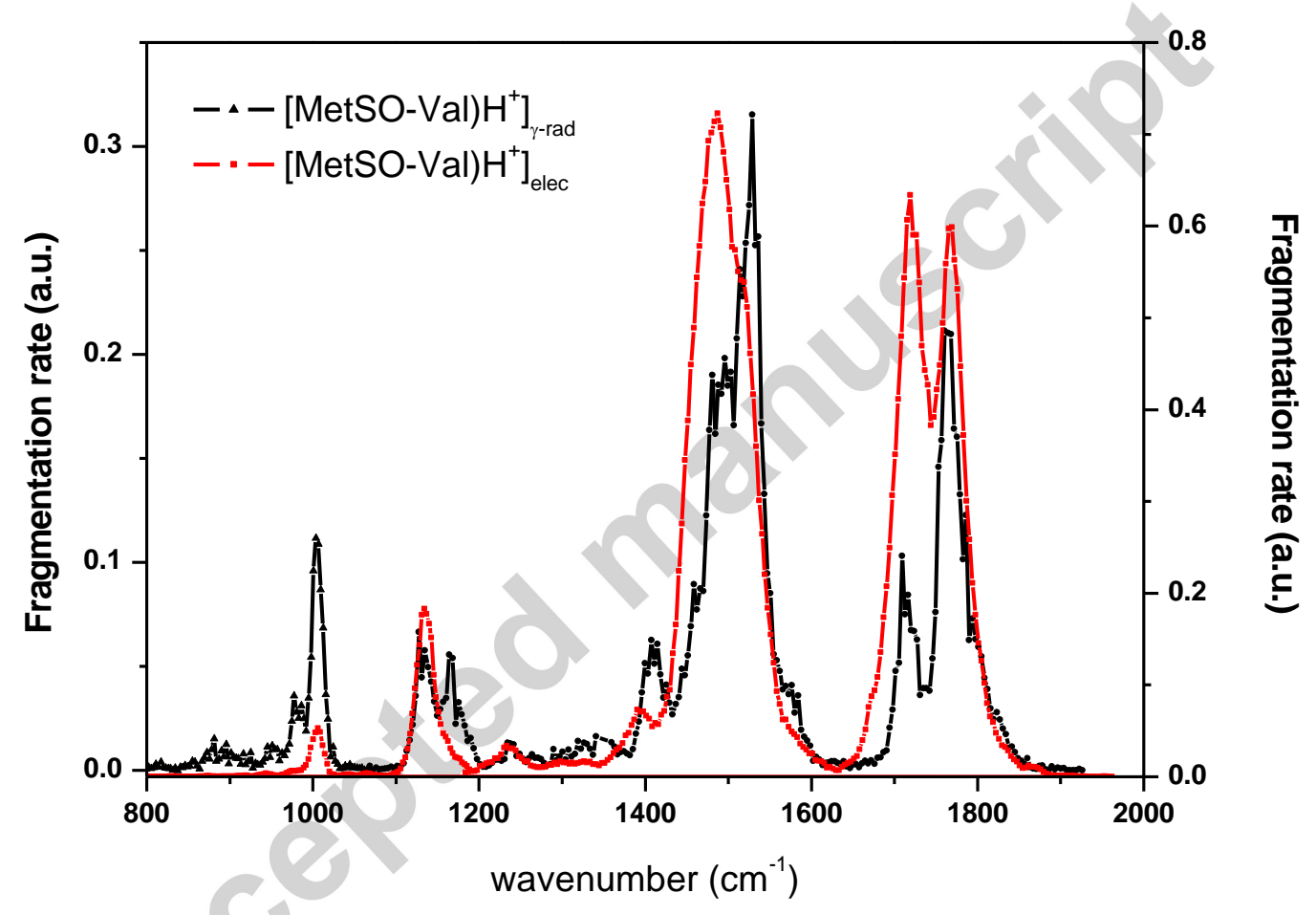

Figure 6: Comparison between the experimental IRMPD spectra of [(MetSO-Val $\left.) \mathrm{H}^{+}\right]$formed by $\gamma$ radiolysis (triangles) and electrolysis (squares) in the $800-2000 \mathrm{~cm}^{-1}$ energy range. 
ACCEPTED MANUSCRIPT

\begin{tabular}{|c|c|c|}
\hline Peptide & Mass increment (+) or decrement (-) (Da) & Products \\
\hline \multirow[t]{3}{*}{ Lys-Met } & +16 & Lys-MetSO \\
\hline & -44 & Ly-Met $-\mathrm{CO}_{2}$ \\
\hline & -19 & $($ Lys-Met $) \mathrm{H}^{+}-\mathrm{NH}_{3}-\mathrm{H}_{2}$ \\
\hline Met-Lys & +16 & MetSO-Lys \\
\hline \multirow[t]{3}{*}{ Met-Tyr } & +16 & MetSO-Tyr \\
\hline & $-28=-44+16$ & (MetSO-Tyr) $-\mathrm{CO}_{2}$ \\
\hline & +32 & MetSO-L-DOPA* \\
\hline \multirow[t]{3}{*}{ Tyr-Met } & +16 & Tyr-MetSO \\
\hline & -44 & Tyr-Met $-\mathrm{CO}_{2}$ \\
\hline & +32 & L-DOPA-MetSO* \\
\hline \multirow[t]{2}{*}{ Met-Val } & +16 & MetSO-Val \\
\hline & -2 & $\operatorname{Met}\left(-\mathrm{H}_{2}\right)-\mathrm{Val}$ \\
\hline \multirow[t]{3}{*}{ Val-Met } & +16 & Val-MetSO \\
\hline & -2 & Val-Met $\left(-\mathrm{H}_{2}\right)$ \\
\hline & -46 & (Val-Met) $-\mathrm{H}_{2}-\mathrm{CO}_{2}$ \\
\hline \multirow{4}{*}{$\begin{array}{l}\text { Met-enkephalin } \\
\text { (Tyr-Gly-Gly- } \\
\text { Phe-Met) }\end{array}$} & $-1(z=2)$ & Met-enkephalin dimer \\
\hline & & (dityrosines) \\
\hline & +32 & Met-enkephalin with DOPA \\
\hline & +16 & Met-enkephalin with $\mathrm{PheOH}$ \\
\hline \multirow{4}{*}{$\begin{array}{c}\text { S-Me- } \\
\text { Glutathione }\end{array}$} & +16 & SO-Me-Glutathione \\
\hline & +32 & $\mathrm{SO}_{2}-\mathrm{Me}-$ Glutathione \\
\hline & -2 & S-Me-Glutathione $-\mathrm{H}_{2}$ \\
\hline & -44 & S-Me-Glutathione-CO2 \\
\hline
\end{tabular}

Table 3: the products detected after oxidation of Met-containing peptides by ${ }^{\circ} \mathrm{OH}$ radicals. MetSO: methionine sulfoxide; L-DOPA: dihydroxyphenylalanine coming from the oxidation of the tyrosine residue; $\operatorname{Met}\left(-\mathrm{H}_{2}\right)$ : methionine having lost 2 hydrogen atoms from its side chain; $\mathrm{PheOH}$ : substitution of $-\mathrm{OH}$ on the aromatic cycle of phenylalanine. ${ }^{*}$ These compounds were formed after irradiation with higher doses (900 Gy).

In many dipeptides we have identified oxidized forms other than sulfoxide. In particular we focused on the oxidation of three peptides, S-methyl-glutathione (GS-Me), tryptophanmethionine and methionine-tryptophan (Trp-Met and Met-Trp) [37].

In GS-Me, we observed that the oxidation resulted mostly in the addition of oxygen atoms to the sulphur, loss of $\mathrm{H}_{2}$ and decarboxylation. Loss of $\mathrm{H}_{2}$ as well as addition of one or two 


\section{ACCEPTED MANUSCRIPT}

oxygen atoms concerned only the thioether moiety, and IRMPD helped to identify the sulfoxide and the sulfone functions.

As for the decarboxylation, the CID-MS ${ }^{2}$ spectrum allowed in this case to localize the decarboxylation site on the Glu residue. Our results suggest that two decarboxylation mechanisms are possible during $\gamma$-radiolysis leading to stable products. The first one, already observed for dipeptides like Lys-Met and Val-Met, requires the presence of a C-terminal methionine and occurs particularly efficiently when both the sulphide function and the carboxylic group are located in the same $\mathrm{C}$-terminal peptide unit. It is considered to proceed via an intramolecular mechanism based on an interaction between the oxidized sulphur function and the carboxylic group. The results observed for the final product of decarboxylation with GS-Me show that the latter may occur not only from the C-terminal but also further up in the sequence. This mechanism supposes the interaction between an ${ }^{\circ} \mathrm{OH}$ radical adduct, formed in the first step of the oxidation, and a protonated amino group in $\alpha$ position relative to a carboxylic group. Oxidative decarboxylation is an important reaction usually observed in the presence of metal ions as catalysts. Such reactions can lead to the development of oxidative stress.

\section{WhAT ABOUt INTRAMOLECULAR ELECTRON TRANSFER INVOLVING METHIONINE?}

Methionine oxidation has been shown to be the precursor of oxidation of other aromatic residues by IET. First we have reinvestigated this phenomenon on dipeptides. IRMPD and fragmentation mass spectra show that after $\gamma$ radiolysis of a solution containing the dipeptide Met-Trp, the first oxygen atom could be added either to the sulphur or to the Trp residue. [37]. Similar results were obtained with Tyr instead of Trp. Only methionine could be oxidized in Trp-Met and the addition of two oxygen atoms has not been observed in our experimental conditions.

\begin{tabular}{|l|l|l|}
\hline Amino acid or residue & $\mathrm{E}^{\circ}(\mathrm{V}$ vs. NHE) & Reference \\
\hline Tyr & $0.85-0.94$ & {$[38]$ and references therein } \\
\hline Trp & 1.05 & {$[39]$} \\
\hline Met & $1.2-1.8$ & {$[17]$} \\
\hline
\end{tabular}

Table 4: the one-electron redox potentials of Tyr, Trp and Met. 


\section{ACCEPTED MANUSCRIPT}

The redox potentials of the residues are gathered in Table 4. That of methionine varies with the sequence, the geometry and the nature of the atom making the $2 c-3 e$ bond [17]. Hence, one would expect fast intramolecular electron transfer (IET) between the Met radical and Trp (or Tyr) in these dipeptides, thanks to the redox potential difference between both residues and the very small distance between them. One would thus expect little oxidation products derived from the Met residue and mostly modifications on the Trp or the Tyr residues. We observe the opposite for Trp, as stated above. Our results are in agreement with those reported for a model protein containing Met and Trp among other residues [40]. Thus, it seems that in these cases the IET, although thermodynamically favoured, can be reversed. Maybe the reactions at the microsecond/millisecond timescales, observable by pulse radiolysis, are followed by slower rearrangements, perhaps due to displacements of redox equilibria.

We have investigated the case of Met-enkephalin, a pentapeptide, in depth. This peptide contains Tyr (N-terminus) and Met (C-terminus). Pulse radiolysis experiments suggested the existence of very fast IET between the methionine radical cation (C-terminus) and the tyrosine residue (N-terminus) [41]. Analysis of the final products led to the conclusion that the Met residue was not oxidized (Table 2), which is in total agreement with the former hypothesis [37]. We also investigated the oxidation of Met-enkephalin by electrochemistry. Interestingly, only the oxidation wave relative to Tyr was visible [42]. The experimental value of the anodic peak in Met-enk $\left(\mathrm{E}_{\mathrm{pa}}=1.05 \mathrm{~V}\right)$ was higher by more than $0.1 \mathrm{~V}$ than the values obtained for Tyr, which may be rationalized by environmental effects.

We had previously performed preliminary theoretical approaches of the oxidation competition between Tyr and Met in isolated peptide models [43]. These first thermodynamic data indicated that $\mathrm{Tyr}^{\circ+}$ was more stable than $\mathrm{Met}^{-+}$. In order to test the thermodynamic feasibility of intramolecular Proton-Coupled Electron Transfer (PCET) in this peptide, we evaluated the redox potentials of each couple involved, i.e. $\mathrm{Met}^{++} / \mathrm{Met}$ and $\mathrm{Tyr}^{+} / \mathrm{Tyr}$ [42]. Because of the size of the peptide, we used QM/MM methods. The peptide underwent the QM/MM partitions depicted in Figure 6. Briefly, in the first one, Met was in the QM part of Met-enk. In the second one, it was the turn of Tyr to be in the QM part of Met-enk. The results are included in Figure 7. They confirm that the redox potential of Met is much higher than that of Tyr and that the IET is thermodynamically allowed. 


\section{ACCEPTED MANUSCRIPT}

\begin{tabular}{|c|c|c|}
\hline $\begin{array}{l}\text { Structure of the } \\
\text { peptide }\end{array}$ & $\begin{array}{c}\mathrm{E}^{\circ}(\text { Tyr } \bullet+/ T y r) \\
\text { V vs. NHE }\end{array}$ & $\begin{array}{c}\left.\mathrm{E}^{\circ} \text { (Met } \bullet+/ \text { Met }\right) \\
\text { V vs. NHE }\end{array}$ \\
\hline & 1.07 & 1.84 \\
\hline & 1.15 & 1.93 \\
\hline
\end{tabular}

Figure 7. The one-electron redox potentials of the Tyr and the Met residues for 2 conformers of Metenkephalin. Calculations were performed using QM/MM methods (see the text).

There is a very good agreement between the measured and the computed values for the Tyr residue. The redox potential of Met is higher than that of Tyr by ca. $800 \mathrm{mV}$, in agreement with the very fast IET observed.

Recently, a study of the IET in one conformation of Met-enkephalin was performed by DFT and MD methods [44]. The most effective ET pathway connects an aromatic hydrogen atom on the tyrosine residue to $\mathrm{CH}_{2}$ group of the methionine residue. It is a "through-space" pathway according to the nomenclature, corresponding to a distance of $3.73 \AA$.

\section{Conclusion}

Since the beginning of the research about protein oxidation, many steps have been unveiled. It is known that protein oxidation can lead to toxic insoluble aggregates and that they cannot be repaired. Methionine oxidation is an important event. It plays roles in fibrillation of $\beta$ amyloid peptide and $\alpha$-synuclein, and thus in Alzheimer's [45,46] and Parkinson's diseases $[47,48]$. Methionine sulfoxide is among the rare oxidized forms that can be repaired. Specific enzymes, known as methionine sulfoxide reductases, aim at reducing the sulfoxide groups. 


\section{ACCEPTED MANUSCRIPT}

Despite the pioneering work of Asmus and co-workers, the chemical mechanism of methionine oxidation is still not understood. It is complex and influenced by atoms and groups of atoms in the vicinity of the Met residue. Now we know that methionine sulfoxide is not the sole product, implying that one cannot expect the total repair of methionine oxidation. Indeed upon photolysis induced oxidation, $100 \%$ of the final compounds were adducts methionine-photosensitizer [49]. All studies by time-resolved methods indicate the involvement of sulphur-centred free radicals, but some final compounds derive from carboncentred ones ([36,49]. So far, no study was able to account for a possible higher stability of carbon-centred radicals with respect to sulphur-centred ones. Finally, the IET events involving Met and aromatics do not always take place despite a very favourable thermodynamic control. There is probably a need for new ways of approaching the subject, both experimental and theoretical.

Acknowledgments: we thank the COST CM0603 and the COST CM1001 Actions for fruitful discussions and financial support. P. Maitre and the mass spectrometry platform at the Laboratoire de Chimie Physique (UMR 8000 CNRS, Université Paris-Sud, Orsay, France) are gratefully acknowledged. The authors thank J. M. Ortega and the CLIO team for technical assistance. The very efficient assistance of V. Steinmetz during the IRMPD experiments is greatly acknowledged. We are indebted to "TGE grand instrument" of the CNRS for financial support.

\section{References}

1. Aruoma OI, Halliwell, B. (1998) Molecular Biology of free radicals in human diseases.

2. Asmus KD (2001) Heteroatom-centered free radicals. Some selected contributions by radiation chemistry. In: Jonah CD, Rao, B.M.S. R., editor. Radiation Chemsitry: present status and future trends. New York: Elsevier.

3. Asmus KD (1979) Stabilization of oxidized sulfur centers in organic sulfides. Radical cations and odd-electron sulfur-sulfur bonds. Accounts of Chemical Research 12: 436442.

4. Bobrowski K, Houée-Levin, C., Marciniak, B. (2008) Stabilization and Reactions of Sulfur Radical Cations: Relevance to One-Electron Oxidation of Methionine in Peptides and Proteins. Chimia 62: 728-734.

5. Ignasiak M, Marciniak, B., Houée-Levin, C (2014) 102. A long story of sensitized oneelectron photo-oxidation of Methionine. Isr J Chem 54: 225-228. 
6. Morozova OB, Korchak SE, Vieth HM, Yurkovskaya AV (2009) Photo-CIDNP study of transient radicals of Met-Gly and Gly-Met peptides in aqueous solution at variable $\mathrm{pH}$. J Phys Chem B 113: 7398-7406.

7. Morozova OB, Korchak SE, Sagdeev RZ, Yurkovskaya AV (2005) Time-resolved chemically induced dynamic nuclear polarization studies of structure and reactivity of methionine radical cations in aqueous solution as a function of $\mathrm{pH}$. J Phys Chem A 109: 10459-10466.

8. Janik I, Tripathi GN (2013) The early events in the OH radical oxidation of dimethyl sulfide in water. J Chem Phys 138: 044506.

9. Bobrowski K, Schoneich, C., Holcman, J., Asmus, K.D. (1991) OH radical induced decarboxylation of g-glutamylmethionine and S-alkylglutathione derivatives: evidence for two different pathways involving $\mathrm{C}$ - and $\mathrm{N}$-terminal decarboxylation. Journal of the Chemical Society-Perkin Transactions 2: 353.

10. Spinks JWT, Woods, R.J. (1990) Introduction to Radiation Chemistry: Wiley New York.

11. Kadlcik V, Sicard-Roselli C, Houee-Levin C, Kodicek M, Ferreri C, et al. (2006) Reductive modification of a methionine residue in the amyloid-beta peptide. Angew Chem Int Ed Engl 45: 2595-2598.

12. Xu G, Chance MR (2005) Radiolytic modification of sulfur-containing amino acid residues in model peptides: fundamental studies for protein footprinting. Anal Chem 77: 2437-2449.

13. Nesbitt DJ, Field RW (1996) Vibrational Energy Flow in Highly Excited Molecules: Role of Intramolecular Vibrational Redistribution. The Journal of Physical Chemistry 100: 12735-12756.

14. Plusquellic DF, Votava O, Nesbitt DJ (1996) Absolute frequency stabilization of an injection-seeded optical parametric oscillator. Appl Opt 35: 1464-1472.

15. Frisch MJ, Trucks, G. W., Schlegel, H. B., Scuseria, G. E. Robb, M. A. , Cheeseman, J. R., Scalmani, G. , Barone, V., Mennucci, B., Petersson, G. A. et al. (2009) Gaussian 09. In: Gaussian I, editor. Wallingford CT USA.

16. Rickards G, Bergès, J., Houée Levin, C. and Rauk, A. (2008) An ab initio and QM/MM Study of Electron Addition on the Disulfide Bond in Thioredoxin. . J Phys Chem B 112: 118-123.

17. Bergès J, de Oliveira P., Fourré, I. Houée Levin C. (2012) The one-electron reduction potential of Methionine-containing peptides depends on the sequence. . J Phys Chem B 116: 9352-9362.

18. Fourré I, Bergès, J. (2004) Structural properties and topological characterization of the three-electron bond: the SO radicals. J Phys Chem A 108: 898-906.

19. Braïda B, Hiberty PC, Savin A (1998) A Systematic Failing of Current Density Functionals: Overestimation of Two-Center Three-Electron Bonding Energies. The Journal of Physical Chemistry A 102: 7872-7877.

20. Becke AD (1993) A new mixing of Hartree-Fock and local density- functional theories. The Journal of Chemical Physics 98: 1372-1377.

21. Adamo C, Barone V (1999) Accurate excitation energies from time-dependent density functional theory: assessing the PBE0 model for organic free radicals. Chemical Physics Letters 314: 152-157.

22. Vetere V, Adamo C, Maldivi P (2000) Performance of the 'parameter free' PBE0 functional for the modeling of molecular properties of heavy metals. Chemical Physics Letters 325: 99-105.

23. Fourré I, Bergès, J. , Houée-Levin, C. (2008) Topological and spectroscopic study of three-electron bonded compounds as models of radical cations of Methioninecontaining dipeptides. chem PhysLett 467: 164-169. 
24. Fourré I, Bergès, J. , Houée-Levin, C. (2010) Structural and Topological Studies of Methionine Radical Cations in Dipeptides: Electron Sharing in Two-Center ThreeElectron Bonds. . J Phys Chem A 114: 7359-7368.

25. Berges J, Varmenot N, Scemama A, Abedinzadeh Z, Bobrowski K (2008) Energies, stability and structure properties of radicals derived from organic sulfides containing an acetyl group after the $* \mathrm{OH}$ attack: ab initio and DFT calculations vs experiment. J Phys Chem A 112: 7015-7026.

26. Brunelle P, Rauk A (2004) One-Electron Oxidation of Methionine in Peptide Environments: The Effect of Three-Electron Bonding on the Reduction Potential of the Radical Cation. The Journal of Physical Chemistry A 108: 11032-11041.

27. Bobrowski K, Hug GL, Pogocki D, Marciniak B, Schoneich C (2007) Sulfur radical cation-peptide bond complex in the one-electron oxidation of S-methylglutathione. $\mathrm{J}$ Am Chem Soc 129: 9236-9245.

28. Kadlcik VS-R, C. ; Houée-Levin, C. ; Kodicek, M.; Ferrer,i C. ; and Chatgilialoglu, C (2006) Angew Chem 45: 2595-.

29. Glass RS, Schöneich C, Wilson GS, Nauser T, Yamamoto T, et al. (2011) Neighboring Pyrrolidine Amide Participation in Thioether Oxidation. Methionine as a "Hopping" Site. Organic Letters 13: 2837-2839.

30. Sicard-Roselli C, Lemaire S, Jacquot JP, Favaudon V, Marchand C, et al. (2004) Thioredoxin Ch1 of Chlamydomonas reinhardtii displays an unusual resistance toward one-electron oxidation. Eur J Biochem 271: 3481-3487.

31. Gillard N, Goffinont S, Bure C, Davidkova M, Maurizot JC, et al. (2007) Radiationinduced oxidative damage to the DNA-binding domain of the lactose repressor. Biochem J 403: 463-472.

32. Mozziconacci O, Mirkowski, J.,Rusconi, F., Pernot, P., Bobrowski, K., Houee-Levin, C. (2007) Free Rad Biol Med: 229-234.

33. Sharp JS, Tomer KB (2007) Analysis of the oxidative damage-induced conformational changes of apo- and holocalmodulin by dose-dependent protein oxidative surface mapping. Biophys J 92: 1682-1692.

34. Kadlick V, Sicard-Roselli,C., Kodicek, M. , Houée-Levin, C. (2004) Free Rad Biol Med 37: 881 .

35. Ignasiak M, Scuderi, D., de Oliveira P., Pedzinski T., Rayah Y., Houee Levin C. (2011) Characterization by mass spectrometry and IRMPD spectroscopy of the sulfoxide group in oxidized methionine and related compounds. . Chem PhysLett 502: 29-36.

36. Ignasiak MT, de Oliveira, P., Houée Levin, C., Scuderi D. (2013) Oxidation of methionine-containing peptides by $\mathrm{OH}$ radicals: Is sulfoxide the only product? Study by mass spectrometry and IRMPD spectroscopy. Chem Phys Lett 590: 35-40.

37. Scuderi D, Ignasiak MT, Serfaty X, de Oliveira P, Houee Levin C (2015) Tandem mass spectrometry and infrared spectroscopy as a tool to identify peptide oxidized residues. Phys Chem Chem Phys 17: 25998-26007.

38. Houee-Levin C, Bobrowski K, Horakova L, Karademir B, Schoneich C, et al. (2015) Exploring oxidative modifications of tyrosine: an update on mechanisms of formation, advances in analysis and biological consequences. Free Radic Res 49: 347-373.

39. DeFelippis MR, Murthy CP, Faraggi M, Klapper MH (1989) Pulse radiolytic measurement of redox potentials: the tyrosine and tryptophan radicals. Biochemistry 28: 4847-4853.

40. Ji JA, Zhang B, Cheng W, Wang YJ (2009) Methionine, tryptophan, and histidine oxidation in a model protein, PTH: mechanisms and stabilization. J Pharm Sci 98: 4485-4500. 


\section{ACCEPTED MANUSCRIPT}

41. Mozziconacci O, Mirkowski, J., Rusconi, F., Kciuk, G., Wisniowski, P., Bobrowski, K.; Houée-Levin, C. (2012) Methionine Residue Acts as a Prooxidant in the •OH-Induced Oxidation of Enkephalins. . J Phys Chem B 116: 9352-9362

42. Berges J, Kamar A, de Oliveira P, Pilme J, Luppi E, et al. (2015) Toward an Understanding of the Oxidation Process of Methionine Enkephalin: A Combined Electrochemistry, Quantum Chemistry and Quantum Chemical Topology Analysis. J Phys Chem B 119: 6885-6893.

43. Trouillas P, Bergès, J., Houée-Levin, C. (2011) towds understanding the protein oxidation processes. $\mathrm{OH}$ addition on tyrosine, phenylalanine or methionine. Int $\mathrm{J}$ Quantum Chem 111: 143-151.

44. Pilmé J, Luppi, E., Bergès, J., Houée Levin, C., De la Lande, A. (2014) Topological analyses of time-dependent electronic structures: application to electron-transfers in methionine enkephalin. Journal of Molecular Modeling 20.

45. He L, Wang X, Zhu D, Zhao C, Du W (2015) Methionine oxidation of amyloid peptides by peroxovanadium complexes: inhibition of fibril formation through a distinct mechanism. Metallomics 7: 1562-1572.

46. Hou L, Lee HG, Han F, Tedesco JM, Perry G, et al. (2013) Modification of amyloidbeta1-42 fibril structure by methionine-35 oxidation. J Alzheimers Dis 37: 9-18.

47. Uversky VN, Yamin G, Souillac PO, Goers J, Glaser CB, et al. (2002) Methionine oxidation inhibits fibrillation of human $\alpha$-synuclein in vitro. FEBS Letters 517: 239244.

48. Glaser CB, Yamin G, Uversky VN, Fink AL (2005) Methionine oxidation, $\alpha$-synuclein and Parkinson's disease. Biochimica et Biophysica Acta (BBA) - Proteins and Proteomics 1703: 157-169.

49. Ignasiak MT, Pedzinski T, Rusconi F, Filipiak P, Bobrowski K, et al. (2014) Photosensitized oxidation of methionine-containing dipeptides. From the transients to the final products. J Phys Chem B 118: 8549-8558.

Highlights

- Methionine oxidation has been reinvestigated by time-resolved, electrochemistry and mass spectrometry methods

- The final compounds have been identified

- Methionine oxidation can be repaired by intramolecular electron transfer in peptides 